\title{
Death Anxiety and Locus of Control during Corona virus (COVID-19) Pandemic in
} Pakistan

\author{
Farah Kiran ${ }^{1}$, Umair Asghar ${ }^{1}$, Saba Arif $^{1}$, Muhammad Arif ${ }^{1}$
}

\begin{abstract}
The Corona virus pandemic is producing significant stress and anxiety for millions of individuals all over the world. All these factors are generating death anxiety for people. This study aimed to assess death anxiety and locus of control among Pakistani population during the COVID-19 pandemic. This study was conducted at The Islamia University of Bahawalpur, Pakistan from March to May 2020. An online survey was conducted using an online questionnaire. A total of 149 responses were received. Descriptive statistics was calculated for demographic variables. t-test, correlation and analysis of variance (ANOVA) were used to test the hypotheses. Results showed statistically significant relationship between death anxiety domains and locus of control except own death and locus of control. The anxiety and apprehensions in society are globally influencing every individual to variable extents. Recent evidence indicates that people who are kept in isolation and quarantine experience substantial distress in the shape of anxiety which are likely to rise progressively during this new pandemic (COVID-19). In this study, participants showed high levels of anxiety regarding death domains and low level of control over their lives.
\end{abstract}

Keywords: Anxiety, COVID-19, Death Anxiety, Death Anxiety Domains, Locus of Control, Pandemic

Received: 18 November 2020; Revised

Received: 03 April 2021; Accepted: 08 May 2021

${ }^{1}$ Research Scholar, Dept of Applied Psychology, The Islamia University of Bahawalpur, Pakistan.

\section{Corresponding Author Email:}

farhamugha1978@gmail.com

\section{Introduction}

The outbreak of this new Coronavirus (COVID-19) pandemic started in December 2019, like a viral outbreak in Wuhan city of central Hubei province of China (Holshue et al., 2020). In the meantime, on 11th January 2020, China revealed its first COVID-19 related death of a 61-year-old man, subjected to the seafood market (WHO, 2020). Throughout the period of some weeks, the virus scattered around the world quickly (WHO, 2020). The World Health Organization (WHO) announced Public Health Emergency of International Concern (PHEIC) on 30th January 2020 (WHO, 2020).

Death anxiety is caused by thoughts of death, feelings of fear or nervousness. It is not still obvious when the pandemic will last, or what the greatness of its influence on the lives of human beings. It has been broadly informed that elderly individuals are extra sensitive to COVID-19, if the person once affected, the outcomes are very serious. Along with the affected, there is a greater amount of death for individuals aged 65 or above (Yang \& $\mathrm{Li}$, 2020).

Locus of control is a psychological construct which is a psychological perception of having control over one's environmental events. Individuals think about themselves

This article is distributed under the terms of the Creative Commons Attribution Non Commercial 4.0 License (http://www.creativecommons.org/licenses/by-nc/4.0/) which permits nonCommercial use, reproduction and distribution of the work without further permission provided the original work is attributed as specified. 
capable to manage their consequences like fear of death due to COVID-19 are identified as internal or having internal Locus of Control (Akin, 2011).

The new pandemic Coronavirus (COVID-19) has resulted in wide-ranging anxiety and hopelessness among countless millions of people and has disrupted organizations and businesses around the world. Locus of control is a model that defines internalized descriptions about "control" or the absence of attitudes and actions during regular periods and in intervals of disaster. Modifications in the locus of control manifest as divergent attitudes and actions in response to crises (Lake, 2020).

As the COVID-19 continues to demonstrate universal awareness, variations occur in

\section{Method}

\section{Research Design}

Cross Sectional and Survey research design was used.

\section{Participants}

The sample consisted of 149 participants. The age range of participants was from 18 to 54 years. The demographic variables included age, gender, education, profession, and marital status. Participants were selected through random selection, with different professions. Data collected through online questionnaires made from Google form. The questionnaire was sent to respondents by using social media apps such as Facebook, WhatsApp, and Instagram to collect participants' responses. The main sample characteristics are presented in Table 1.

\section{Inclusion/Exclusion Criteria}

Individuals with age range 18 years to 54 years were included in the present study while individuals below 18 years and above 54 years were not included in the study.

\section{Measures}

For measuring death anxiety, the CollettLester fear of death scale is used. This scale consists of 36 items. Total responses are 6 people's self-esteem; at the stage of personalities, groups, and principles, will influence their opinions, and activities, resulting in substantial alterations in the hazard of contagion and death whereas, locus of control describes people's general behavior toward internal and external attitudes.

The present research hypothesized that:

1. There is an association between Death anxiety and Locus of Control in individuals during coronavirus (COVID-19) pandemic.

2 . Death anxiety would perceive more and locus of control less in female participants.

3. Death anxiety would perceive less and locus of control more in male participants.

4. Single people have more death anxiety than married people.

$(+1,+2,+3,-1,-2,-3)$ positive sign shows agreements; higher the positive option, strong will be the agreement, whereas higher the negative option, strong will be the disagreement. This scale is further divided into 4 subscales. The four subscales are: fear of death of self, fear of dying of self, fear of death of others, and fear of dying of others. The reliability of these subscales according to test-retest method were 0.85 for self-death, 0.79 for self-dying, 0.86 for fear of others death, and 0.83 for others dying. The Splithalf reliability of these subscales was 0.91 , $0.89,0.72$, and 0.87 respectively. The itemstotal correlation of these subscales ranged from 0.36 to 0.78 and the median correlation was 0.62 (Lester, 1990).

The locus of control scale was developed by Nowicki and Strickland in 1973. This scale consists of 40 items. It measures locus of control of the participants. Responses are yes/No. The test-retest reliability of this scale is 0.63 and 0.66 . Split-half reliability of this scale is 0.63 and 0.68 , respectively (Nowicki \& Strickland, 1973). 


\section{Procedure}

This study was conducted from March to May 2020. Approval letter was taken from the Head of the Department for the collection of data. Willingly participants were administered an online survey using Google forms; its whole administration took about 20-25 minutes. The participants were informed that there were no right, or wrong questions and they should try to be as honest as possible in their responses. Participants were informed that the data they have delivered would be used for the study purpose only. The participants filled out demographic questionnaires and the questionnaire of death anxiety and locus of control.

\section{Results}

\section{Table 1}

Descriptive Statistics of Demographic Variables $(N=149)$

\begin{tabular}{llll}
\hline Demographic Variable & Characteristics & Frequency & Percentage \\
\hline Age & $18-24$ & 127 & 85.2 \\
& $25-34$ & 17 & 11.4 \\
& $35-44$ & 3 & 2.0 \\
Gender & $45-54$ & 2 & 1.3 \\
\hline Education & Male & 48 & 32.2 \\
& Female & 101 & 67.8 \\
& Matric or less & 6 & 4.0 \\
& Inter & 31 & 20.8 \\
& Bachelors & 72 & 48.3 \\
Profession & Masters & 36 & 24.2 \\
& MPhil/PhD & 4 & 2.7 \\
\hline Marital Status & Student & 123 & 82.6 \\
& Govt. employee & 7 & 4.7 \\
& Private job & 7 & 4.7 \\
& Business & 12 & 8.1 \\
\hline & Single & 133 & 89.3 \\
& Married & 15 & 10.1 \\
\hline
\end{tabular}

The Table 1 describes the frequency distribution of demographic variables of the study. The majority was female participants $(68 \%)$ whereas $32 \%$ were male participants. $85 \%$ of the participants that scored higher in death anxiety were students (young adult age). Majority 48\%) had bachelors 'education followed by $24 \%$ who had master education. Around 83\% were students and $90 \%$ of the participants were single. 
Table 2

Correlations between Death Anxiety Domains and Locus of Control $(N=149)$

\begin{tabular}{lllllllll}
\hline Variables & $\mathbf{N}$ & $\mathbf{M}$ & SD & $\mathbf{1}$ & $\mathbf{2}$ & $\mathbf{3}$ & $\mathbf{4}$ & $\mathbf{5}$ \\
\hline Own Death & 149 & 28.16 & 6.04 & - & & & \\
Own Dying & 149 & 25.25 & 5.66 & $.48^{* *}$ & - & & & \\
OtherDeath & 149 & 25.24 & 5.62 & $.54 * *$ & $.54 * *$ & - & \\
OtherDying & 149 & 27.38 & 5.44 & $.45^{* *}$ & $.62^{* *}$ & $.55^{* *}$ & - \\
Locus Ctrl & 149 & 23.60 & 4.38 & -.15 & $-.25^{* *}$ & $-.19^{*}$ & $-.22^{* *}$ & - \\
\hline
\end{tabular}

$* * p<0.01$

$* p<0.05$

In Table 2, results showed correlation of death anxiety domains and locus of control which is statistically significant. There are statistically significant relationships among death anxiety domains and locus of control

There is significant negative association among death anxiety domains such as own dying, others death, and others dying and locus of control except own death.

except own death.

Table 3

Results of t test $(N=149)$

\begin{tabular}{lcccccc}
\hline Gender & \multicolumn{3}{c}{ Males $(\mathbf{n = 4 8})$} & \multicolumn{3}{c}{ Females $(\mathbf{n = 1 0 1})$} \\
\hline Variables & $\mathbf{M}$ & SD & M & SD & $\boldsymbol{t}(\mathbf{d f})$ & Sig. \\
\hline Own Death & 28.56 & 5.19 & 27.98 & 6.42 & $.59(112.35)$ & .55 \\
Own Dying & 25.45 & 6.14 & 25.15 & 5.45 & $.30(147)$ & .76 \\
Other Death & 24.12 & 5.37 & 25.78 & 5.68 & $-1.69(147)$ & .09 \\
Other Dying & 26.81 & 5.14 & 27.65 & 5.59 & $-.88(147)$ & .38 \\
LOCtrl & 23.87 & 4.55 & 23.47 & 4.32 & $.51(147)$ & .60 \\
\hline
\end{tabular}

In Table 3, gender differences find out by using t-test in death anxiety domains and locus of control are presented. The results are not statistically significant for each death anxiety domain and locus of control. There are no significant gender differences in death anxiety domains and locus of control. 
Table 4

Analysis of Variance for Marital Status wise Difference in Death Anxiety Domains $(N=149)$

\begin{tabular}{llllll}
\hline Marital Status & Single & Married & Divorced & F (2) & Sig. \\
\hline Variables & $\mathbf{M}(\mathbf{S D})$ & $\mathbf{M}(\mathbf{S D})$ & $\mathbf{M}(\mathbf{S D})$ & & \\
\hline Own Death & $28.10(6.14)$ & $28.46(5.42)$ & 32.00 & .22 & .80 \\
Own Dying & $25.02(5.75)$ & $27.13(4.74)$ & 28.00 & 1.05 & .35 \\
Other Death & $25.06(5.48)$ & $26.60(6.89)$ & 29.00 & .72 & .48 \\
Other Dying & $27.15(5.53)$ & $29.33(4.51)$ & 28.00 & 1.08 & .34 \\
Locus Ctrl & $23.48(4.24)$ & $23.93(5.10)$ & 34.00 & 2.97 & .05 \\
\hline
\end{tabular}

The Table 4 gives results of ANOVA test which was applied to find the variance between death anxiety domains and locus of control in people with different marital status.

\section{Discussion}

The objective of the study was to evaluate associations between death anxiety domains and locus of control. The result indicates that death anxiety domains and locus of control except own death are negatively correlated. Means, if death anxiety increases, locus of control decreases. Those participants which have high level of locus of control have less level of death anxiety. It was found that death anxiety of the single respondent is greater than married respondents, means single respondents have less locus of control, although, the difference was not statistically significant.

It was hypothesized that male participants have a high level of locus of control and less level of death anxiety and female participants show high level of death anxiety and less level of locus of control. This was due to that females are more sensitive in nature. However, the statistical analysis found no significant differences between gender for each death anxiety domain and locus of
The results are not statistically significant for each death anxiety domain and locus of control. There are no significant differences in people with different marital status.

control. Furthermore, this research has shown that men and women had different correlates of death anxiety. This principle should be further explained in reference to the concepts of individual differences research (Eshbaugh \& Henninger, 2013).

The findings supported that individuals in the high death anxiety group did have a lower locus of control than individuals in the low death anxiety group. A recent study recommended that people with high locus of control would display less anxiety about death-related acts (Zhang et al., 2019).

Moreover, the findings showed that there was a statistically significantly negative association between death anxiety domains and locus of control. Previous research studies also reported that death anxiety was found greater in young, single adults (Bluntschli et al., 2015; Hallberg, 2013) although, the present study did not report similar findings. 


\section{Limitations}

Few potential limitations are observed in this study due to country-wide lockdown. Quantitative method is used in this study, so the in depth responses could not be collected. Similarly, the sample has been taken from few cities of Pakistan; it should not be generalized to the whole population of

\section{Conclusion}

The present study maintained the significant association between death anxiety domains and locus of control in the participants due to COVID-19 pandemic. All domains of death anxiety except own death were negatively

\section{Conflict of Interest}

The authors declared no conflict of interest.

\section{References}

Akin, A. (2011). Academic loss of control and Self handicapped. Procedia Social and Behavioral Sciences, 30, 812-816. http://doi.org/10.1016/j.sbspro.2011.10. 157

Bluntschli, J. R., Maxfield, M., Grasso, R. L., \& Kisley, M. A. (2015). The Last Word: A Comparison of Younger and Older Adults' Brain Responses to Reminders of Death. Journal of Gerontology: Psychological Sciences, 73, 555-563. http://doi.org/10.1093/geronb/gbv115

Eshbaugh, E., \& Henninger, W. (2013). Potential mediators of the relationship between gender and death anxiety. Individual Differences Research, 11(1), 22-30.

Hallberg, I. R. (2013). Death and dying from old people's point of view. A literature reviews. Aging Clinical and Experimental Research, 16, 87-103. https://doi.org/10.1007/BF03324537

Holshue, M. L., DeBolt, C., Lindquist, S., Lofy, K. H., Wiesman, J., Bruce, H., Spitters, C., Ericson, K., Wilkerson, S., Tural, A., Diaz, G., Cohn, A., Fox, L., Patel, A.,
Pakistan. The people who had mobile phones and internet connections could only participate in this research. Number of respondents reached was less. The death anxiety and locus of control in other individuals may be distinct from the conclusions of our study.

correlated with locus of control. There were found no significant gender and marital status wise differences in death anxiety domains and locus of control.

\section{Source of Funding}

The authors stated no source of funding.

Gerber S.I., Kim L., Tong S., Lu X., Lindstrom S., Pallansch M.A., Weldon W.C., Biggs H.M., Uyeki T.M., Pillai S.K. (2020). First case of 2019 Novel Coronavirus in the United States. The New England Journal of Medicine, 382(10), 929-936. https://doi.org/10.1056/NEJMoa200119 1

Lake M. D. J. (2020, April 05). Locus of control and COVID-19. Psychology Today https://www.psychologytoday.com/intl/ blog/integrative-mental-healthcare/202004/locus-control-and-covid19.

Lester, D. (1990). The Collect-Lester fear of death scale: the origin and a revision. Death Studies, 14, 451-468.

Nowicki, S. \& Strickland, B., R. (1973). The Locus of Control Scale for children. Journal of Consulting and Clinical Psychology, 40(1), 148-154.

World Health Organization. (2020, January 30). Statement on the second meeting of the International Health Regulations (2005). Emergency Committee regarding the 
outbreak of novel coronavirus (2019nCoV). https://www.who.int/newsroom/detail/30-01-2020-statement-onthesecondmeeting-of-the-internationalhealth-regulations-(2005)emergencycommittee-regarding-theoutbreakof-novel-coronavirus-(2019ncov)

Yang, J., \& Li, H. (2020). The impact of aging and COVID-19 on our immune system: a high-resolution map from single cell analysis. Protein Cell, 11(10), 703-706. http://doi.org/10.1007/s13238-02000782-y

Zhang, J., Peng, J., Gao, P., Huang, H., Cao, Y., Zheng, L., \& Miao, D. (2019). Relationship between meaning in life and death anxiety in the elderly: Self-esteem as a mediator._BMC Geriatrics $\quad 19, \quad 308$. https://doi.org/10.1186/s12877-019-

1316-7 